\title{
COMMENTARY ON "MULTIEMPLOYER BARGAINING RULES": SEARCHING FOR THE RIGHT QUESTIONS
}

\author{
Jan Vetter*
}

$\mathrm{O}$ NE way of investigating a topic is to look at it in the light of insights gained elsewhere. This is what Professor Douglas Leslie recommends in his very interesting article. He takes a number of ideas that have been developed within the law and economics inoveinent and juxtaposes thein with the legal rules governing inultieinployer bargaining, specifically with rules applying to withdrawal froin multiemployer bargaining units. The outcome of the enterprise is the suggestion of a series of questions liaving to do witl various issues, including the competing explanations of the parties' incentives to adopt inultieinployer bargaining (sucli as "cartelization" versus "wage premiun"" theory versus "relative wage" theory); the possible sources of transactions costs in collective bargaining (sucl as "batcll" theory and "framing device" theory); and the criteria of clioice between "precise" and "inultifactored" rules. Althougl conceding that the questions he has raised are "devilishly difficult," Leslie concludes by expressing confidence that these are the "appropriate questions."

Altlough I am in no position to be anything otlier tlian agnostic to sucl1 an economic analysis, I am inclined to loope that these are not the appropriate questions, or at least not tlie only questions. Leslie's questions can be answered, if at all, ouly by extensive study of unions and einployers engaged in their customary pursuits. Thus, as they stand, the questions are not very useful to lawyers, governmental agencies, and judges in the ongoing process of fitting doctrine to litigated disputes. Moreover, I do not believe tliat we have a kennel full of social scientists baying to be set on the trail of these questions. I therefore do not think there is inuch prospect of usable answers to these questions einerging anytime soon.

A second way to proceed witlı some subject of interest is to begin by inaking explicit whiat we think we know and then to ask where our account seems inadequate or in need of support. In this Commentary, I will briefly attempt this type of investigation and suggest an approacl to multiemployer bargaining that contrasts with that by Leslie. I do not inean to imply that what I say will be uncontroversial or universally accepted. I believe, however, that it will come within a familiar range of discourse and thus be readily digestible in the continumg professional dialogue on multiemployer

* Associate Dean and Professor of Law, University of California, Berkeley (Boalt Hall). 
bargaining. Further, where my approach leaves unanswered questions, the questions will be, for better or worse, of the kind we are accustomed to addressing in hitigation.

\section{The INCIDENCE of Multiemployer Bargaining}

The structural condition necessary to multieinployer bargaining exists where there are two or inore competing employers whose employees are represented by the same umion. In this setting, the union will most likely try to standardize wages and other terms of employment. This is not because unions generally seek to equalize pay throughout their constituency or within an occupation. On the contrary, unions may very well bargain to discriminate annong employers according to ability to pay. When this occurs, however, the discrimination is likely to fall between employers in different businesses, as when job-shop printers are paid less than printers employed by newspapers; or, if it falls within the same business, between noncompeting employers in different markets. Among competing employers in the saine market, the union will push for, while it is also pulled toward, the goal of equal pay for equal work. Competition im the product market may leave the parties, both union and employers, with no alternative. At the saine time, equal pay for the saine work reflects a popular sense of justice widely shared among employees, and its pursuit deflnes a pohtical mission for the union, while employers do not willingly accept a competitive disadvantage im labor costs even when offsetting advantages allow it. In fact, this preference for equal employment terms has at times prevented unions from tapping an employer's high profits when a competing employer remained im a relatively weak financial position. ${ }^{1}$

If collective bargaining by competing employers with a common union is a necessary condition of multiemployer bargaining, it is plainly not a sufficient condition. In many such situations, multiemployer bargaining does not occur. The union instead conducts parallel negotiations with imdividual employers for separate agreements while trying, perhaps with considerable success, to standardize their terms. Two questions present themselves: When two or more competing employers are organized by the same urion, why is not there always multiemployer bargaining, or, alteruatively, why is there ever bargaining im this forn?

Multiemployer bargaining is common in both westeru Europe and in the

1 For example, through the years that closely similar employment terms were maintained in the Umited States auto industry, Chrysler's relatively weak capacity to pay stood immovably between the United Automobile Workers and General Motors' high profits. 
United States, and is reportedly nuore widespread in the former. ${ }^{2}$ In the United States, the National Labor Relations Board (Board) insists that inultientployer bargaining is conditioned on the consent of the parties. ${ }^{3}$ Although it inay be true that powerful unions or dominant employers have sometimes succeeded $\dot{n} 1$ conscripting unwilling eniployers into inultien1ployer groups, it reinains evident that, at least im the United States, parties most often enter into nultiemployer relationships willingly and reniain in them of their own volition. To the extent that multieniployer bargaining rests on a basis of consent, its existence must be explained in terms of nicentives adequate to attract the loyalty of both sides.

To say this, however, seenis to propose a paradox (as Leshe notes). Multiemployer bargaining is often thought to eularge the eniployers' power relative to that of the union. Why, then, would the union consent to such a reduction in its bargaining strength? If, on the other hand, it is not correct that employers gain strength relative to that of the union by uniting in multieniployer groups, why do eniployers agree to bargain on this basis? In the next Part of this Commentary, I exannine these questions.

\section{INCENTIVES}

It is said that competing eniployers inay be put at a competitive disadvantage by separate negotiations with the saine union. ${ }^{4}$ The union 1nay "whip-

2 Compare Schmidt, Industrial Action: The Role of Trade Unions and Employer's Associations, in Industrial Conflict: A Comparative Legal Survey 13-15 (B. Aaron \& K.W. Wedderburn eds. 1972) (discussing employer's associations in Great Britain); id. at 43-47 (discussing "industry" or "multi-enterprise" agreentents in West Germany); XV International Encyclopedia of Comparative Law IT 12-107, -111 (1984) [hereinafter Encyclopedia] (same); Schmidt, supra, at 53 (discussnig entployer's associations in France); XV Encyclopedia, supra, If 12-191 (same); Schmidt, supra, at 35-36 (discussing employer's associations or "confederations" in Sweden and other Scandinavian countries); XV Encyclopedia, supra, If] 12-156, -161 (same) with Schmidt, supra, at 22-23 (discussing multieniployer bargaining arrangements in the United States); XV Encyclopedia, supra, II 12-223, -232 (same). For more recent statistics on the number of multiemployer agreemeuts in the United States, see Bureau of Labor Statistics, U.S. Dep't of Labor, Bull. No. 2065, Characteristics of Major Collective Bargaining Agreements-Jan. 1, 1978, at 12 table 1.8 (1980), cited in Charles D. Bonanno Linen Serv., Inc. v. NLRB, 454 U.S. 404,410 n.4 (1982).

3 The Board will not establish a multiemployer unit over any party's objection, see Umited Fryer \& Stillman, Inc., 139 N.L.R.B. 704 (1962), and the Board has held that the use of economic force to compel other parties to bargain on a multiemployer basis violates the right of each party to select its own bargaining representative. See United Mine Workers, Local No. 1854 (AMAX Coal Co.), 238 N.L.R.B. 1583 (1978).

4 See, e.g., A. Cox, D. Bok \& R. Gorman, Cases and Materials on Labor Law 303 (10th ed. 1986) ("The multientployer pattern may reflect the desire of several small employers who seek greater leverage in dealing with a single common union ...."). For a good general discussion of several of the suggested notivations for multieinployer bargaining, see id. at 303-06. 
saw" the einployers by striking against them in sequence, one at a time. As the union strikes against each employer while the einployer's competitors continue operations, the diversion of the struck employer's customers places it under great pressure to make concessions to the union. Meanwhile, the union expends less of its resources than it would have expended in a strike against all the employers. By exploiting the whipsaw tactic, the union extends uniform terms throughout the product inarket at a higher level than it could have reached if it had confronted all the employers at once in a straightforward test of economic strength. Multiemployer bargaining, it is argued, legitinizes the lockout-that is, when the union strikes against one employer, the others can respond by locking out their employees, treating a strike against one as a strike against all. In maintaining discipline in the face of a whipsaw strike (that is, by locking out), the nonstruck employers can prevent the union from enlistimg them as unwilling allies against the struck employer, as well as raise the uinon's costs of striking.

If this analysis is accepted, it may explain why employers are willing to join in a multiemployer bargaining unit, but at the cost of making a puzzle of the union's consent. If the union's choice is between obtaining uniform terms through a single negotiation with the multiemployer group or achievmg higher uniform terms through separate, parallel negotiations with the employers individually, the union might be expected to choose the latter alternative.

Before advancmg some additional considerations that may push unions toward multiemployer bargaining, I should qualify somewhat the argument just presented to account for employers' interest in this bargaining structure. In saying that multiemployer bargaining "legitimizes" the lockout, I ain invoking an underlying assumption that employers can lock out to counter a whipsaw strike ouly in the-setting of formal multiemployer bargaining. The legal history of this assumption, however, is more complicated.

In 1950, in its first ruling on the lockout as a response to the whipsaw strike in multiemployer bargaining, the Board held the tactic to be illegal. ${ }^{5}$ At that time, the Board considered any lockout to be an unfair labor practice unless it fell within a narrowly defined "defensive" category, such as a lockout to preempt a strike that would cause exceptionally severe operational losses. ${ }^{6}$ The Board's unwillinguess to characterize multiemployer lockouts as defensive (and thus permissible) met an unsympathetic reaction in the federal courts of appeal. ${ }^{7}$ Because of this reaction, and perhaps because of a

5 See Morand Bros. Beverage Co., 91 N.L.R.B. 409 (1950), enforced in part, remanded in part, 190 F.2d 576 (7th Cir. 1951).

6 Id. at 411-12.

7 See Leonard v. NLRB, 205 F.2d 355 (9th Cir. 1953); Leonard v. NLRB, 197 F.2d 435 (9th Cir. 1952); Morand Bros. Beverage Co. v. NLRB, 190 F.2d 576 (7th Cir. 1951). 
change in the Board's membership following the replacement of a Democratic with a Republican administration im 1952, the Board in 1954 changed its view, and the Umited States Supreme Court ultimately agreed with the changed position in 1957, upholding the legality of the multiemployer lockout. $^{8}$ The next important development occurred in 1965, when the Court collapsed the Board's distmction between "defensive" and "offensive" lockouts and upheld the lawfulness of a single employer's lockout designed simply to exert economic pressure on the union for the purpose of winning concessions from the union in collective bargaining. ${ }^{9}$ As the Board quickly recognized, the Court's decision seemed to imply that an employer could lock out employees represented by a union that had, in separate negotiations, struck against a competing employer over a similar demand. ${ }^{10}$ In effect, pursuant to the Court's 1965 decision, it would appear that an employer may lock out im what can be ouly functionally defined as a inultiemployer bargaining situation, as well as in one formally established by mutual consent.

In sun, the legality of the inultiemployer bargaining lockout was not clearly establisleed until 1957, and the Board clearly and decisively distmguished between lockouts in formally and functionally defined multiemployer settings from ouly 1957 to 1965 . Before 1957, unions did not necessarily lose legal protection against lockouts by agrecing to multiemployer bargaining, and since 1965 they liave not necessarily maintained such protection by withholding agreement. Notwithstanding the lockout's legal vicissitudes, multiemployer bargaining has been a common practice over the entire period.

This history suggests two points. First, even thougl the parties may attach great importance to the prospect of whipsaw strikes and the availability of lockouts in response, these factors are not the only, nor necessarily the dominant, considerations influencing the parties' clooices. Second, over at least inost of the post-World War II period, unions, in agreeing to multiemployer bargaining, have not given up as inuch as might be supposed. Before 1957 , they could hope that they gave up nothing. Since 1965, there may lave been nothing to give up.

It may be true, nevertheless, that by entering into multiemployer bargaining, unions may significantly enlarge the scale of any conflict that may occur. Further, by bargaining with employers' associations, they may settle

8 See NLRB v. Truck Drivers Local No. 449 (Buffalo Linen Supply Co.), 353 U..S. 87 (1957).

9 See American Ship Bldg. Co. v. NLRB, 380 U.S. 300 (1965).

10 See The Evening News Ass'n, 166 N.L.R.B. 219 (1967), petition for review denied sub nom. Newspaper Drivers \& Handlers' Local No. 372 v. NLRB, 404 F.2d 1159 (6th Cir. 1968), cert. denied, 395 U.S. 923 (1969). 
on terms less favorable than might have been won by bargaining separately with individual employers. There are, however, offsetting considerations. The union aims to standardize terms of employment, and joint bargaining for a single agreement greatly facilitates achievement of that goal. Many negotiations are reduced to one. The employers haininer out among themselves, rather than with the umon, their different rankings of the issues that make up the bargaining agenda. A single agreement imposing uniform terms on all employers greatly simplifies administration of the relationship. Where there are many small employers or employees working short periods for different employers, as in construction and stevedoring, creation of a simgle unit aggregates employees into a base large enough to support group benefit plans. The efficiencies of multiemployer bargaining may benefit union officials, as well as the union's membership, because part of the gam generated by the officials' increased productivity no doubt accrues to them as higher compensation.

In addition, multiemployer bargaining enhances the union's protection against rival unions, disaffected employees, and hostile employers. When bargaining is conducted on a single employer basis, the employees of each individual employer constitute the relevant group for determining representation. When the union and a group of employers agree to joint bargaining, the appropriate unit expands to mclude the union-represented employees of all the employers. Consequently, a rival union must organize a much larger group of employees if it hopes to replace the incunibent union as collective bargaining representative. The union can no longer be decertified by vote of the employees of one employer but only by a vote of employees im the multiemployer group as a whole. No individual employer can withdraw recognition of the umion on the ground that it no longer represents a majority of that employer's employees; rather, it is majority standing im the overall group that counts.

It is also possible that in some situations bargaiming on a multiemployer basis increases the employers' willingness to make concessions. Their competition with each other may not allow significant variation im labor costs, but if all competitors unite in the multiemployer group under one agreement, none of them is placed at a competitive disadvantage when they joimtly make uniform concessions to the union. If they bargained individually, however, each employer would fear that it might give more than another employer and would therefore resist the union's demands more strongly.

Finally, in examining union mcentives to grant or withhold consent to multiemployer bargaining, it is useful to recognize that it may not be best to describe unions narrowly as economic institutions. We might conceive of unions as institutions trying to reach the combination of total employment and level of compensation that maximizes the employers' labor costs. We 
are probably better advised, however, at least for some purposes, to consider unions as political institutions more interested in producing soine level of satisfaction among their membership than in inaximizing the return to their economic strength. ${ }^{11}$ Although multiemployer bargaining may reduce the efficacy of the whipsaw strike and decrease by soine uncertain and speculative amount the economic gams of the union's constituency, it inay also better satisfy that constituency's sense of equity by more reliably standardizing terms of einployment and by doing so at a lower level of conflict.

The incentives for einployers to form a multiemployer unit have already einerged. Competing employers gaim protection against disadvantageous differentials in labor costs. In addition, by engaging in multieinployer bargaining, einployers avoid the difficulties that result from separate bargaining, such as gauging just the right mix of resistance and concession. Further, with multiemployer bargaining there is no legal risk in locking out, and there is a preexisting, mutual commitment to do so if the union should resort to a whipsaw strike.

\section{Disincentrves}

Given all of these perceived benefits of inultiemployer bargaining, the question remams why it is not more widespread than it is. There inay be many reasons, varying from one situation to another, why parties on either side might withhold consent. Two possible cases will be suggested here. First, when a union represents the einployees in an oligarchic industry, it may try to induce the few, prosperous employers to share their monopoly rents with their unionized einployees. In this situation, parallel negotiations combined with the whipsaw strike nay be nost effective in securing large, uniform gains at a tolerable cost, and, thus, the union will be inclined to resist multiemployer bargaining. Second, in inarkets with one dominant firm, single einployer bargaming may be one means by which that firm realizes the advantages of its position. This case inay be illustrated witl a hypothetical instance that shared some common features with the United States auto industry until recently.

Let us suppose that one firm, General Motors (GM), is dommant and is twice as large as its nearest competitor. The heavy costs of striking against GM will deter the union froin doing so. (For example, strike benefits are expended at twice the rate of a strike against the next largest firm.) Consequently, the union will usually select a conpeting firm as the target of a whipsaw strike through which it will try to set the pattern for the industry. In settling with the target firm, however, the union will be careful not to settle at a level higher than GM is willing to accept; if GM was a formidable

11 For development of this view at length, see A. Ross, Trade Union Wage Policy (1948). 
opponent earher, it is doubly so after the union has waged a strike elsewhere. Indeed, it would not be startling to find some communication between the union and GM about the acceptable size of the settlement at the target firm.

Under these circunistances, there may be little mcentive for the dominant firm to enter into multiemployer bargaining. In separate bargaining, the dominant firm's direct losses due to strikes will, over time, be less than that of its competitors, and its influence on the outcome of bargaining will remain predommant. Moreover, the dominant firm can more easily preserve some terms it has negotiated that are more favorable than those negotiated with other firms.

\section{The Bonanno Case}

In his article, Leslie apphies his theoretical apparatus to a recent United States Supreme Court decision, Charles D. Bonanno Linen Service, Inc. v. $N L R B .{ }^{12}$ In this case, the union struck against Bonanno Linen Service (Bonanno), a member of a multiemployer group, after an impasse had been reached during negotiations for a new collective bargaining agreement. In response, "most" of the other ten members of the group locked out. ${ }^{13}$ Several months later, Bonanno, having permanently replaced its striking employees and resumed operations, announced its withdrawal from the multiemployer group. ${ }^{14}$ The other employers ended the lockout and over the next several months negotiated an agreement with the umion. The Board held that the agreement bound Bonanno because its withdrawal had been untimely and thus meffective. ${ }^{15}$

Under established Board doctrine, once parties consent to multiemployer bargaining, they can withdraw only if they give adequate notice to the other parties before the scheduled date of negotiations for a new agreement or before the actual commencement of negotiations. Once negotiations have commenced, withdrawal is not permitted absent "mutual consent" or "unusual circunistances."16 "Unusual circunistances" have been himited to cases of extreme financial pressure on an employer or extensive fragmentation of the unit through withdrawals that had occurred without objection. ${ }^{17}$ Bonanno would have added cases in which impasse had been reached in bargaining to this categorical exception. The Board rejected this position,

12454 U.S. 404 (1982).

13 Id. at 407.

14 Id.

15 Id. at 408.

16 See Retail Assocs., Inc., 120 N.L.R.B. 388, 395 (1958) (dictum).

17 See, e.g., Typographic Serv., Co., 238 N.L.R.B. 1565 (1978) (employer withdrawal due to excessive fragmentation); U.S. Lingerie Corp., 170 N.L.R.B. 750 (1968) (employer withdrawal due to its extreme economic difficulties/bankruptcy). 
and a majority in the Supreme Court agreed. ${ }^{18}$

Leshe is uncertain how Bonanno should have been decided because he lacks the information required to characterize adequately multiemployer bargaining within the theoretical scheme he outlines. I would be willing to support on narrow grounds the Board's ruling that, because Bonanno's attempted withdrawal was untimely, it should be held to the agreement eventually negotiated. The argument in support of a right of employer withdrawal on impasse, developed in. several cases in the federal courts of appeal ${ }^{19}$ and adopted in Chief Justice Burger's dissenting opinion in Bonanno, ${ }^{20}$ was that such a right balances the union's right to use the whipsaw strike and to enter into imterim agreements with defecting employers. I would say that granting the right of withdrawal on inıpasse is arbitrary in relation to the policy these courts would serve of matching the employers' arsenal with that of the union. What might arguably follow from the view that whipsaw strikes and interim agreements create an imbalance of power in favor of the union would be a rule that employers could withdraw on the occurrence of these events. Bonanno's attempted withdrawal may well have been motivated instead by a desire to challenge the union's majority status in a unit comfined to its own employees, who were strike replacements and could be presumed to be hostile to the union.

\section{CONCluding COMMENTS}

The Bonanno case and Leshe's discussion of it raise a more general issue: Do the Board's rules too tightly constrain withdrawal from multiemployer bargaining? I share Leshe's uncertainty. I do beheve that effective bargaining requires a stable framework, and this implies restraints on withdrawal, although not necessarily just the ones the Board has adopted. Moreover, I would probably ask questions different from, though not necessarily opposite to, those offered by Leshe. I would be influenced mostly by indications that the Board's interpretations of the National Labor Relations Act ${ }^{21}$ (Act) led to large-scale defections from multiemployer bargaining, either by unions or employers. This is because I think that the history of the Taft-Hartley amendments to the Act in $1947^{22}$ estabhshed a place for multiemployer bar-

18 Bonanno, 454 U.S. at 412.

19 See, e.g., NLRB v. Independent Ass'n of Steel Fabricators, 582 F.2d 135 (2d Cir. 1978), cert. denied, 429 U.S. 1130 (1979); 1 Sec. of Lab. \& Enipl. L., A.B.A., The Developing Labor Law 481-82 \& n.394 (C. Morris 2d ed. 1983) (citations omitted).

20 See 454 U.S. at $423-25$.

21 Ch. 372, 49 Stat. 449 (1935) (codified as amended at 29 U.S.C. $\$ \S 151-169$ (1982)).

22 Labor-Management Relations Act, ch. 120, 61 Stat. 136 (1947) (codified as amended in scattered sections of 18,29 U.S.C.). 
gaining within the regime of industrial relations that the Act sponsors. ${ }^{23}$ Whether that notoriously elusive phenomenon-an imbalance of powerexists as such seems to me largely irrelevant within the general scheine of the Act.

23 See NLRB v. Truck Drivers Local No. 449 (Buffalo Linen Supply Co.), 353 U.S. 87, 94 96 (1957). 